Z. Klin. Chem. Klin. Biochem.

13. Jg. 1975 , S. 533-539

\title{
Rapid Lactate Determination with an Electrochemical Enzymatic Sensor: Clinical Usability and Comparative Measurements
}

\author{
By Ph. Racine \\ Bioelectronics Department F. Hoffmann-La Roche \& Co., Ltd. Basle, Switzerland \\ and \\ H.-O. Klenk and K. Kochsiek \\ Medizinische Universitätsklinik, Abteilung Innere Medizin III (Direktor: Prof. Dr. Kochsiek) Tübingen, Germany
}

(Eingegangen am 7. Dezember 1974/23. Mai 1975)

Summary: Lactate measurements can be performed within 2-3 minutes after blood withdrawal from the patients by using an electrochemical enzymatic sensor for lactate. The values obtained reflect the actual state of the patient which is not the case with the slow classical method using lactate dehydrogenase and NAD.

The sensor is reproducible and the influence of the main reducing substances found in the blood is small enough to be of no clinical significance. Drugs commonly used in intensive care stations have no influence on the sensor. In vitro lactate production of the blood cells has been studied under various conditions.

66 pairs of comparative measurements between the classical method and the lactate sensor resulted in a good correlation coefficient.

Schnelle Bestimmung von Lactat mit einem elektrochemisch-enzymatischen Sensor: Klinische Brauchbarkeit und vergleichende Messungen

Zusammenfassung: Die Lactatbestimmung im Blut innerhalb von 2-3 Minuten nach Blutabnahme wird durch einen elektrochemisch-enzymatischen Sensor ermöglicht. Die erhaltenen Werte geben den tatsächlichen Zustand des Patienten wieder, was mit der langsamen, klassischen Methode unter Verwendung von Lactatdehydrogenase und NAD nicht möglich ist.

Die mit dem Lactatsensor erhaltenen Werte sind reproduzierbar. Der Einfluß der wichtigsten reduzierenden Substanzen im Blut ist sehr gering und nicht von klinischer Bedeutung. Medikamente, die in der Intensivpflege oft verwendet werden, haben keinen Einfluß auf den Sensor. Die in vitro Lactatproduktion der Blutkörperchen wurde unter verschiedenen Bedingungen untersucht.

Es wurden 66 Vergleichsmessungen zwischen der klassischen Methode und dem Lactatsensor durchgeführt. Der Korrelationskoeffizient ist gut.

\section{Introduction}

Many critically sịck patients develop acidosis as a result of profound respiratory, hemodynamic and/or metabolic abnormalities. Plasma lactate elevations commonly result from metabolic disturbances producing acidosis particularly with associated vascular collapse. Measurement of serum or blood lactate would be of great help in distinguishing lactic acidosis from other causes and in the following treatment. Even though lactic acidosis is found in a variety of clinical circumstances, serum lactate levels are obtained much less frequently than are the other measurements of the acidotic state such as $\mathrm{pH}$ and carbon dioxide tension.
A combination of problems generally makes the procedure for lactate determination too expensive to perform regularly for sick patients. Lactate is being formed in vitro so any delay between drawing the sample, separating the red cells and stopping their metabolism will increase the lactate levels. In most laboratories lactate is not determined routinely so that even "stat" samples may be delayed long enough that the results no longer accurately reflect the patient's state.

Some delay is also unavoidable because of the time required to perform a single lactate determination. Since lactate levels are of greatest use for critically ill patients, the determination must reflect rapidly changing clinical 
conditions and must be compatible with the work schedules of a busy staff. A technically simple device which would rapidly measure lactate would solve these problems, particularly if it were simple enough to be actually used by the staff caring for the patient. It is our purpose to describe our experience with a semiautomatic device which can be used to determine lactate levels in a clinical setting by personnel not specifically trained for the task.

\section{Sensor}

D. L. Williams et al. (4) were the first to report lactate measurements using an electrochemical enzymatic sensor. This method was later improved by $P h$. Racine $(5,6,7)$ and coworkers. With the device used here, lactate measurement is based on the specific and irreversible oxidation of $L$-lactate to pyruvate in the presence of an electron acceptor (hexacyanoferrate(III)) and the enzyme cytochrome $b_{2}$ from baker's yeast (Saccharomyces cerevisiae):

$$
\begin{aligned}
(\text { Lactate })^{-1} & +2 \mathrm{Fe}(\mathrm{CN})_{6}{ }^{-3} \stackrel{\text { cytochrome } \mathrm{b}_{2}}{\longrightarrow}(\text { Pyruvate })^{-1} \\
& +2 \mathrm{H}^{+}+2 \mathrm{Fe}(\mathrm{CN})_{6}{ }^{-4}
\end{aligned}
$$

The hexacyanoferrate(II) is reoxidized at a platinum electrode biased at $0.25-0.40$ volts against a silver-silver chloride electrode.

$2 \mathrm{Fe}(\mathrm{CN})_{6}^{-4} \stackrel{\mathrm{Pt}}{\rightarrow} 2 \mathrm{Fe}(\mathrm{CN})_{6}^{-3}+2 \mathrm{e}^{-}$

Thus in response to the presence of $L$-lactate, the sensor develops a current which is linearly related to the external concentration of this substrate.

A scheme of the sensor is shown in figure 1.

It consists of a slightly recessed disc-shaped platinum electrode covered with a layer of enzyme solution. A semipermeable cellophane membrane separates the enzyme layer from the test solution allowing diffusion of lactate and hexacyanoferrate(III) but preventing enzyme from leaking into the test solution. As counter electrode, a silver-silver chloride electrode separated from the test solution by a glass-frit is used.

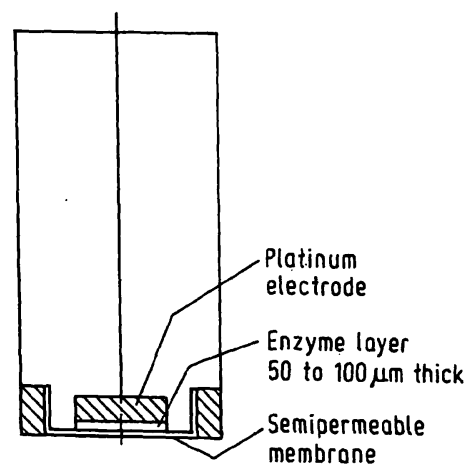

Fig. 1. Scheme of the lactate sensor
Using membranes made from regenerated cellulose (DUPONT PUDO 193) and enzyme solutions of about $2000 \mathrm{kU} / 1\left(\right.$ at $\left.25^{\circ} \mathrm{C}\right)$ the sensor gives a linear calibration curve for about 4 weeks in the range $0-1.5 \mathrm{mmol} / 1$. The response time of a sensor varies initially from 40 secounds at the end of its useful life time.

The intrinsic reproducibility of the sensor response is good, as can be seen from the recordings of its output current for two different lactate standards (fig. 2). A deviation not exceeding $1 \%$ is routinely observed during daily calibrations of the instrument.

When the sensor response ceases to be linear or becomes too slow due to the inevitable denaturation of the enzyme, the membrane is discarded and the platinum surface cleaned by an anoding etching. Fresh enzyme suspension $(1 \mu \mathrm{l}) \mathrm{kept}$ in saturated ammonium sulfate is then placed on the platinum electrode and a new membrane is fitted after it has been soaked in bi-distilled water for at least one minute. The sensor can thus be used for several weeks to perform several hundred lactate assays.

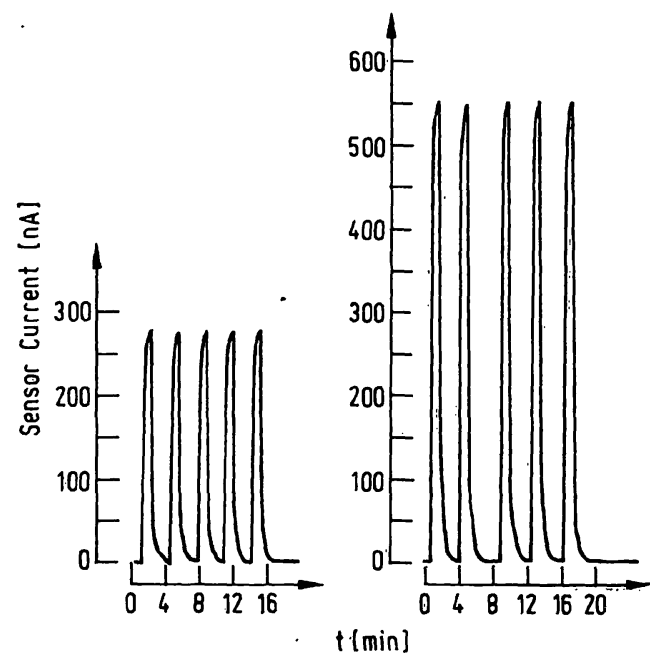

Fig. 2. Recording of the sensor current after the injection of 0.5 (left) and 1.0 (right) $\mathrm{mmol} / 1$ lactate standard.

\section{Instrument and Sample Measurement}

A prototype of a semi-automatic Lactate Analyzer has been developed and its functions have been described in a recent publication (8). In the study reported here, an earlier laboratory prototype was utilized whose essential functions do not differ from the latest unit. The heart of the instrument is a plexiglass measurement cell containing the sensor and the counter electrode. The total volume from sample inlet to outlet is $100 \mu$ land the volume between the electrodes $(70 \mu 1)$ is thermostated at $20^{\circ} \mathrm{C}$. Figure 3 is a schematic diagram of the measurement system and figure 4 a picture of the instrument. Emptying and washing of the cell is automatic and the readout is analog. Calibration is performed 


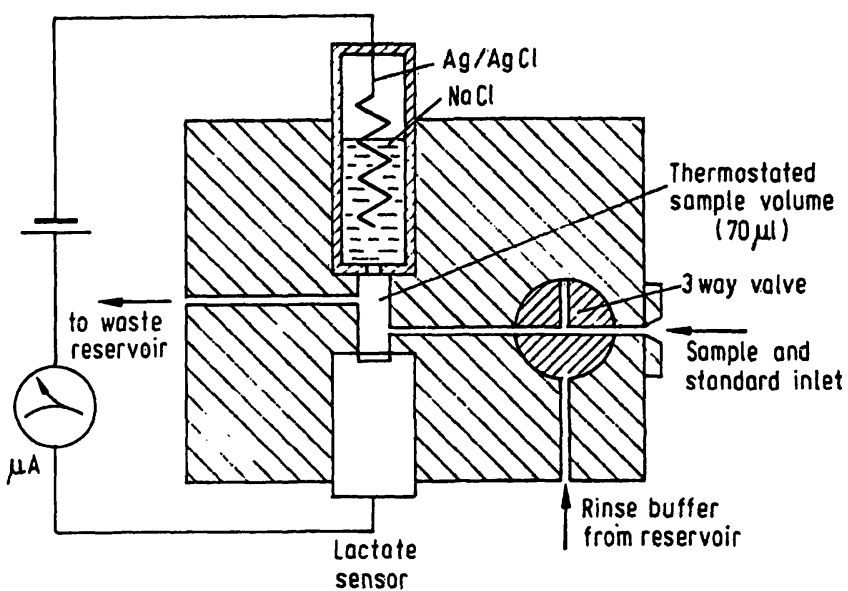

Fig. 3. Schematic diagram of the measurement system

twice daily with a standard of $1.00 \mathrm{mmol} / \mathrm{l}$ by adjusting the readout on $10.0 \mathrm{mmol} / \mathrm{l}$ with the calibration potentiometer. Linearity is then checked with a standard of $0.50 \mathrm{mmol} / 1$.

Physiological lactate levels can be above $10 \mathrm{mmol} / \mathrm{l}$, thus the sample is diluted 10 times prior to measurement. A sample of at least $50 \mu \mathrm{l}$ of whole blood is taken and diluted 10 times with an isotonic phosphate buffer $\left(\mathrm{pH}=7.3,0.10 \mathrm{~mol} / 1+2 \mathrm{~g} / \mathrm{l} \mathrm{NaF}+1 \mathrm{~g} / 1 \mathrm{NaN}_{3}\right)$. $0.50 \mathrm{ml}$ of this diluted sample are injected into the measurement cell. The same volume of standard is used for calibration. Between measurements the cell is rinsed using a solution of $0.2 \mathrm{~mol} / \mathrm{l}$ phosphate buffer $(\mathrm{pH}=7.3$ ) containing $2.0 \mathrm{mmol} / 1$ hexacyanoferrate(III).

\section{Method}

Sixty-six comparative measurements of blood were used to calculate the correlation between the enzymatic method performed in the laboratory of the "Medizinische Universitätsklinik, Tübingen" and the Lactate Analyzer. The enzymatic spectrophotometric determinations were performed according to the method of Hohorst (12), which was checked by Linden (13).

The lactate determination with the Lactate Analyzer was pcrformed according to the above method. Immediately after withdrawal, $100 \mu \mathrm{l}$ whole blood were diluted 10 times with the isotonic phosphate buffer $(0.1 \mathrm{~mol} / 1 \mathrm{pH}=7.3) .0 .50 \mathrm{ml}$ of this diluted sample were injected into the measurcment cell using a disposable $2 \mathrm{ml}$-syringe. The readout followed between 40-60 seconds. Thereafter and just before the next measurement was started the cell was rinsed with $0.2 \mathrm{~mol} / \mathrm{l}$ phosphate buffer, $\mathrm{pH}=7.3$, containing $2.0 \mathrm{mmol} / 1$ hexacyanoferrate(III). Each sample was detcrmined twice and the mean value is shown in table 1 .

Blood was withdrawn, without heparin addition, from a freely flowing brachial vein, a femoral artery or from the pulmonary artery during cardiac catheterization. The samples were processed immediately. In 7 cases it was not possible to perform the lactate determination immediately. Five of these were diluted in phosphate buffer + sodium fluoride $(2 \mathrm{~g} / 1)$ at a ratio of $1: 10$ and stored in an ice bath. For two, the blood was heparinized and placed in the ice bath immediately. These 7 samples were chemically analyzed between 20 and 60 minutes following blood withdrawal.

Blood cells continue to produce lactate when citrated or heparinized blood is allowed to stand at room temperature. Furthermore during a series of preliminary measurements it had been observed that lactate also rose when diluted blood samples were left standing at room temperature. To test this observation and to get an optimum determination of lactate, $10 \mathrm{ml}$ heparinized blood was taken from 7 subjects. From each sample, $3 \mathrm{ml}$ of the blood were poured immediately into a second tube. Two $\mathrm{ml}$ of blood were pipetted into a third and fourth tube which contained $8 \mathrm{ml}$ of $0.1 \mathrm{~mol} / \mathrm{l}$ phosphate buffer $+2 \mathrm{~g} / \mathrm{l} \mathrm{NaF}$. The second and fourth tubes were immediately placed into an ice

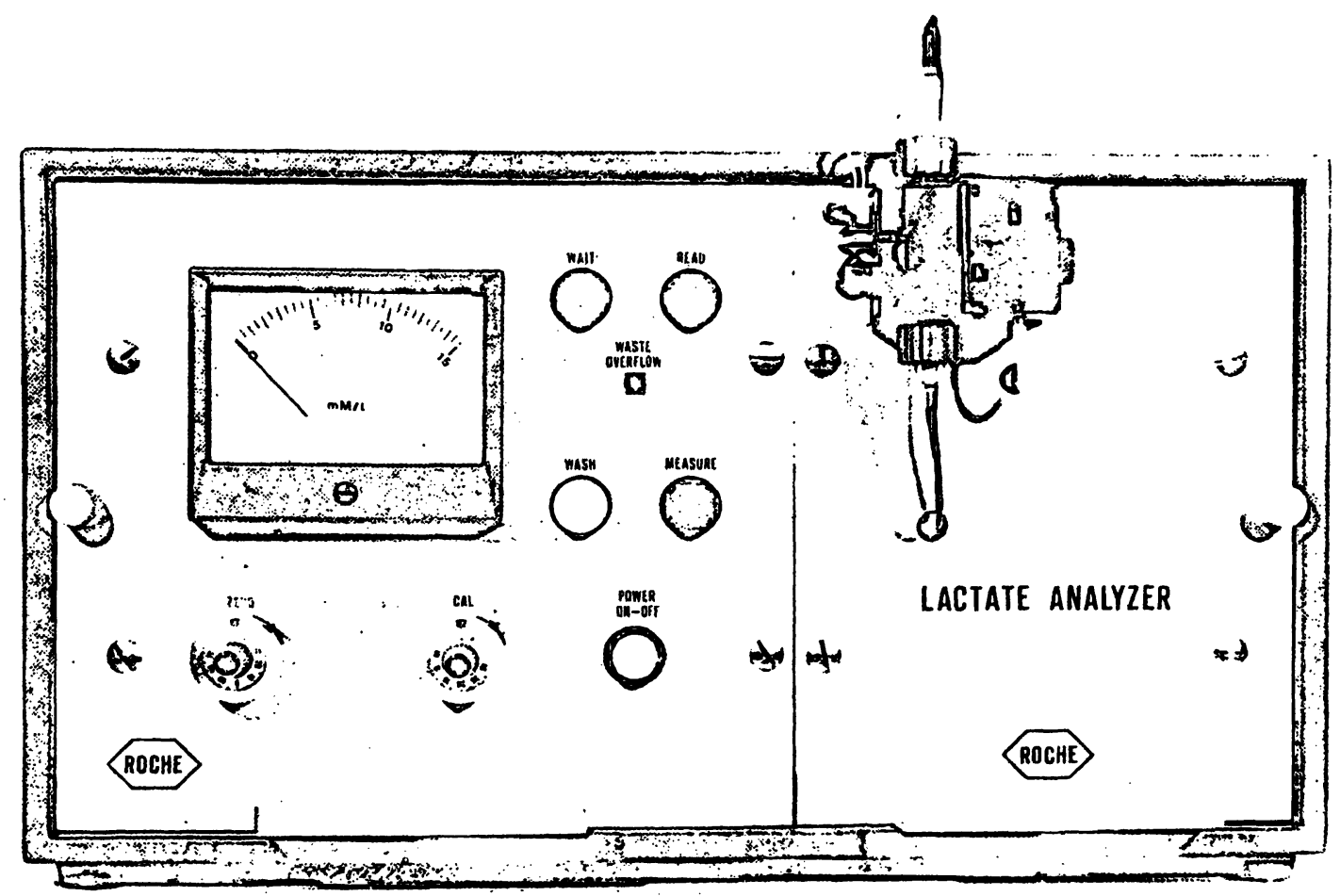

Fig. 4. Prototype of the Lactate Analyzer 
Tab. 1. Lactate values obtained with the classical method and the Lactate Analyzer

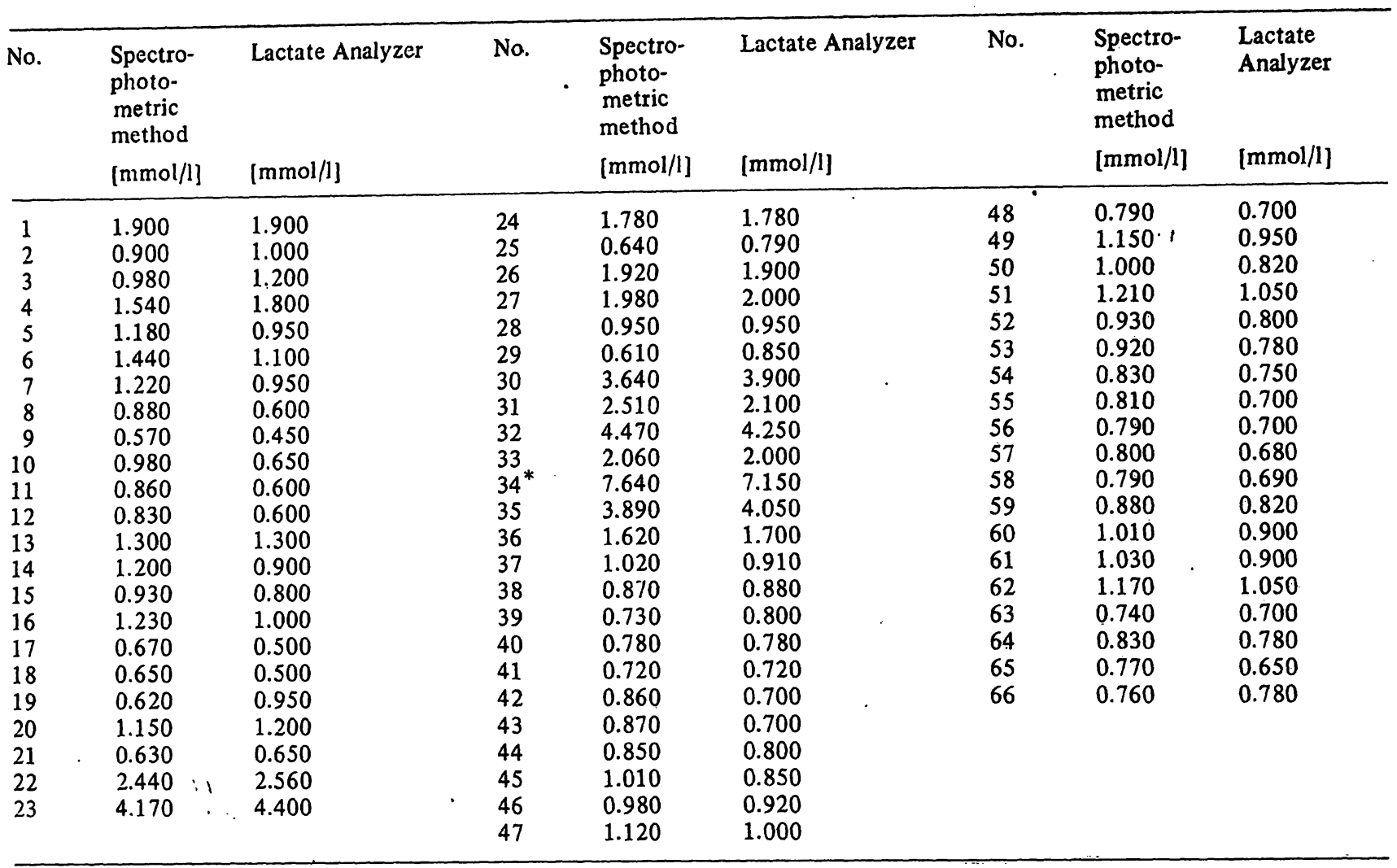

* Error in the setting of the dilution ratio

bath. The first and third tubes were kept at room temperature. The first measurement of lactate was started within 4 minutes after blood sampling. The lactate concentrations from tubes $1,2,3$ and 4 vere sequentially measured at $3-4$ minute intervals until the 72 nd minute. Thereafter, measurements were made at the 80 th, 90 th, 110 th and 120 th minute. The dilution ratio for these measurements was 1:5 (blood: $0.1 \mathrm{~mol} / 1$ phosphate buffer). Calibrations were made before starting the measurements, in the 75th minute and after their completion. All measurements were made with the Lactate Analyzer according to the above method.

The reaction catalyzed by cytochrom $b_{2}$ is specific for $L$-lactate, but other substrates can react with reduced efficiency $(9,10)$. The most active are $\alpha$-hydroxy- $n$-butyrate, $\alpha$-hydroxy$n$-caproate and $\alpha$-hydroxy-isocaproate. Only $\beta$-hydroxy- $n$ butyrate is encountered in blood where it reaches concentrations of $10 \mathrm{mmol} / \mathrm{l}$ in diabetic patients. To test this, $0.1,1.0$ and $10 \mathrm{mmol} / 1 \beta$-hydroxy-n-butyrate (Merck) were prepared in a $0.1 \mathrm{~mol} / \mathrm{l}$ phosphate buffer at $\mathrm{pH}$ of 7.3 . These were compared with a $1.0 \mathrm{mmol} / \mathrm{l}$ lactate standard prepared in the same buffer.

It has been reported (6) that blood reducing substances are capable of either reducing the acceptor, hexacyanoferrate(III) or being oxidized at the platinum electrode. Some of these substances were added to the $10 \mathrm{mmol} / \mathrm{l}$ lactate standard and the resulting changes determined. These are shown in table 4. Low concentrations of certain drugs can act as inhibitors or activators of enzyme activity. Drugs often prescribed for critically ill patients were tested using a $1.0 \mathrm{mmol} / 1$ lactate standard to which the drug was added. Tible 5 shows the concentrations of these drugs.

\section{Results}

All comparative measurements are given in table 1.

Table 2 shows the correlation coefficient and the re-
Tab. 2. Correlation coefficient for the comparative measurements

\begin{tabular}{lc}
\hline Number of measurements pair & 66 \\
Correlation coefficient & 0.990 \\
Regression line & \\
- Intercept $\mathrm{a}_{0}$ & $0.055 \pm 0.032$ \\
- Slope $\mathrm{a}_{1}$ & $0.988 \pm 0.018$
\end{tabular}

gression equation for these values. There is a good correlation $(r=0.990)$. Figure 5 shows the regression line with the $95 \%$ confidence level for the data points.

The results of incubation measurements are given in table 3 and plotted on figure 6 . The mean percent increase \pm the standard deviation from the first measurement is shown for the 7 samples. The initial lactate values were between 0.6 and $2.0 \mathrm{mmol} / 1$. The results show that there is a continuous and nearly linear increase in lactate concentration when heparinized blood is stored at room temperature. However, if heparinized whole blood is placed in an ice bath, there is no increase in lactate concentration over 120 minutes.

Blood diluted with buffer containing $\mathrm{NaF}$ and stored at room temperature showed an initial increase in measured lactate. This increase was more rapid than the increase observed in undiluted blood during that period of time $(p<0.05)$. The rapid increase in apparent lactate level stops after 20-30 minutes. When heparinized blood 
Tab. 3. In vitso effect of temperature and diution in Naf contuining buffer on blood lactate levels

\begin{tabular}{|c|c|c|c|c|c|}
\hline \multicolumn{3}{|c|}{ Heparinized whole blood at room temperature $\left(23^{\circ} \mathrm{C}\right.$ ) } & \multicolumn{3}{|c|}{ Heparinized whole blood in ice bath } \\
\hline $\begin{array}{l}\text { Incubation } \\
\text { time } \\
\text { [min] }\end{array}$ & $\begin{array}{l}\text { Lactate increase } \\
{[\%]} \\
\bar{x} \neq 5\end{array}$ & $\begin{array}{l}\text { Siznificance } \\
\text { level }\end{array}$ & $\begin{array}{l}\text { Incubation } \\
\text { time } \\
\text { [min] }\end{array}$ & $\begin{array}{l}\text { Lactate increase } \\
{[\%]} \\
x \pm 3\end{array}$ & $\begin{array}{l}\text { Significance } \\
\text { Jevel }\end{array}$ \\
\hline $\begin{array}{r}17 \\
32 \\
43 \\
57 \\
80 \\
110\end{array}$ & $\begin{array}{l}13.8=3.74 \\
20.6=4.33 \\
31.5=11.9 \\
45.5=21.9 \\
61.0=22.8 \\
89.9 \pm 32.4\end{array}$ & $\begin{array}{l}2 p<0.001 \\
2 p \\
2 p \\
2 p \\
2 p \\
2 p\end{array}$ & $\begin{array}{r}7 \\
21 \\
34 \\
48 \\
61 \\
44 \\
114\end{array}$ & $\begin{aligned}-4.8 & =8.53 \\
-4.8 & =8.53 \\
-3.3 & =6.07 \\
-2.1 & =5.4 \\
-1.3 & =5.9 \\
+0.1 & =7.2 \\
1 . y & =5.9\end{aligned}$ & $\begin{array}{l}2 p<0.2 \\
2 p \\
2 p \\
2 p \\
2 p \\
2 p \\
2 p\end{array}$ \\
\hline
\end{tabular}

Diluted blood at room temperature

\begin{tabular}{rll}
11 & $21.8 \pm 8.77$ & $2 p<0.001$ \\
24 & $27.9 \pm 8.06$ & $2 p$ \\
37 & $30.9 \pm 10.03$ & $2 p$ \\
51 & $31.0 \pm 8.27$ & $2 p$ \\
65 & $32.4=9.7$ & $2 p$ \\
87 & $33.7 \pm 9.0$ & $2 p$ \\
117 & $36.5=9.2$ & $2 p$ \\
\hline
\end{tabular}

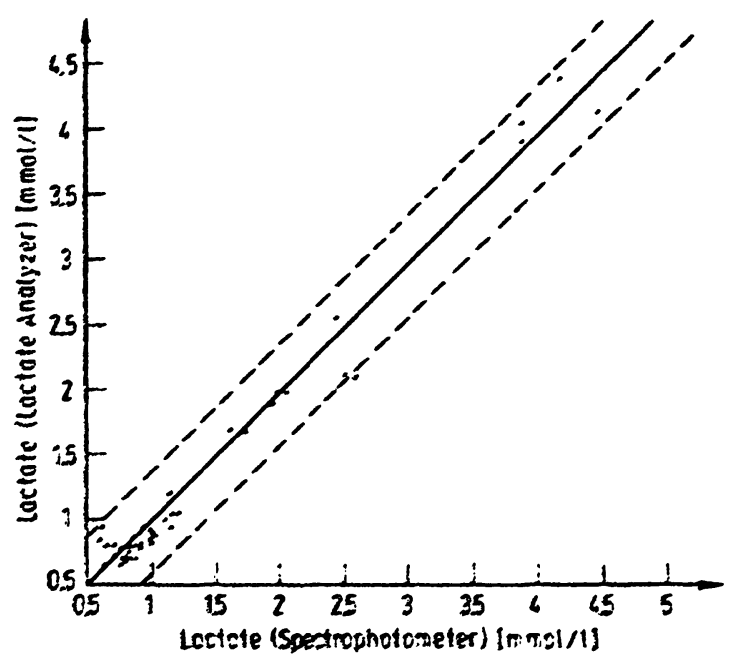

Fig. 5. Regression line for the correlation between the values of the Lactate Analyzer and the spectrophotometric method regression line

$95 \%$ confidence level data points

was diluted with $\mathrm{NaF}$ containing buffer and stored in an ice bath, no change in lactate level was noted.

Table 4 shows the effect various reducing substances in the blood have on the measured lactate level. It can be seen that $11.9 \mathrm{mmol} / \mathrm{l}$ of uric acid increases the measured lactate level to $0.3 \mathrm{mmol} / \mathrm{L}$. The other reducing substances showed smaller and clinically negligible effects. A slight diminution in apparent lactate levels occurs with some substances like cysteine, whereas when $L$-lactate is not present a small increase in current occurs which could be read as lactate. Table 5 shows that none of the drugs tested caused a change in the lactate reading. $\beta$ hydroxy-n-butyrate at concentrations of $0.1,1.0$ and $10 \mathrm{mmol} / 1$ showed no effect.
Diluted blood in ice besth

\begin{tabular}{rll}
14 & $-0.6=1.8$ & $2 p<0.5$ \\
28 & $0=0$ & - \\
40 & $0=5$ & - \\
54 & $00 \pm 0$ & - \\
6,8 & $0=0$ & - \\
90 & $0=0$ & - \\
121 & $0=0$ & - \\
\hline
\end{tabular}

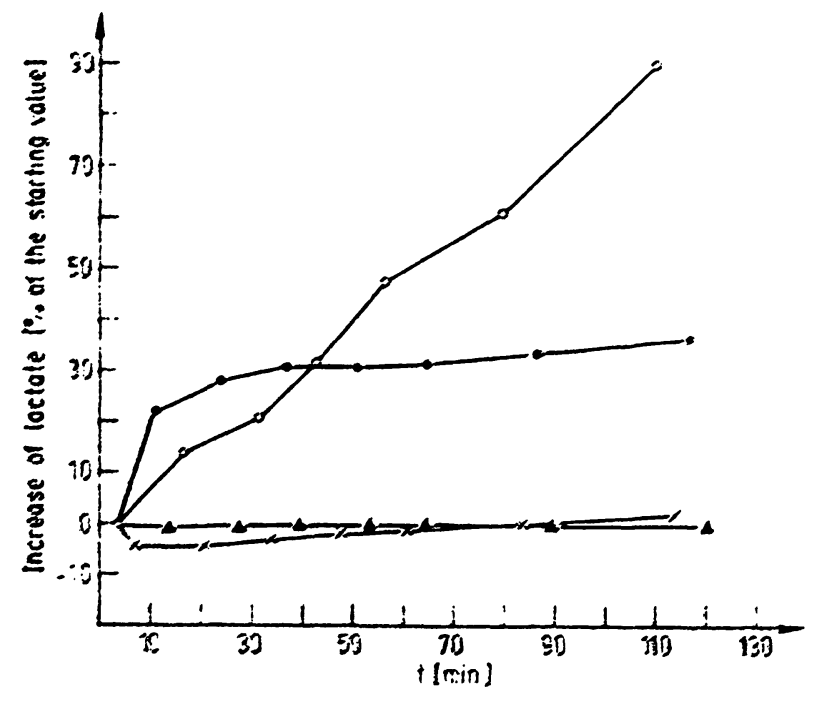

Fig. 6. Change of lactate concentration over 120 minutes in whole and diluted blood at room temperature and on ice " whole blood at $25^{\circ} \mathrm{C}$

$x \longrightarrow x$ whole blood on ice

- diluted bloosd at 25 "C

a_diluted blood on ice

Tab. 4. Effect of various blood reducing substances on the reading of the lactate sensor

\begin{tabular}{lllc}
\hline Substance & $\begin{array}{l}\text { Normal blood } \\
\text { level } \\
\text { [mmol/] }\end{array}$ & $\begin{array}{l}\text { Concentration } \\
\text { used } \\
\text { [mmol/1] }\end{array}$ & $\begin{array}{l}\text { Apparent } \\
\text { change } \\
\text { [mmol/1] }\end{array}$ \\
\hline Ascorbic acid & $\mathbf{0 . 0 4 - 0 . 1 4}$ & 0.14 & 0 \\
B-Alanine & 0.45 & 0.56 & 0 \\
Creatinine & 0.04 & 0.44 & -0.15 \\
Cystine & 0.08 & 0,08 & -0.1 \\
Gycine & 0.27 & 0.67 & -0.05 \\
GSH & 1.14 & 1.30 & 0 \\
Lrea & 3.33 & 9.99 & 0 \\
Uric acid & $\mathbf{0 . 1 8 - 0 . 3 6}$ & 1.19 & +0.3 \\
Salicylate & $?$ & 2.17 & 0 \\
Adreneline & $\mathbf{0 . 0 0 1 4}$ & 0.014 & 0 \\
\hline
\end{tabular}


Tab. 5. Influence of commonly used drugs in intensive care stations

\begin{tabular}{lcl}
\hline Active substance & $\begin{array}{c}\text { Concentration } \\
{[\mathrm{mg} / \mathrm{l}]}\end{array}$ & $\begin{array}{l}\text { Change' in } \\
\text { sensor reading } \\
{[\mathrm{mmol} / \mathrm{l}]}\end{array}$ \\
\hline Lanatosid C & 0.13 & 0 \\
Eraldin & 2 & 0 \\
$p$-Amino N 2 diethyl- & & \\
aminoethylbenzamide HCl & 170 & 0 \\
Propanolol & 4 & 0 \\
Lidocaine & 200 & 0 \\
Diphenylhydantoin Na & 10 & 0 \\
\hline
\end{tabular}

\section{Discussion}

The blood handling tests indicate that at room temperature there is a continuous increase in the lactate concentration of whole blood over the observation time of 120 minutes. The lactate increase is due to continued lactate production by blood cells. When samples are placed in an ice bath, the metabolic processes are blocked and lactate production stops.

J. O. Westgard et al. (11) have shown that the lactate concentration is stable when whole blood is mixed with a sodium fluoride solution $(2 \mathrm{~g} \mathrm{NaF} / \mathrm{l})$ and centrifuged within 15 minutes after blood collection. They reported that whole blood containing $\mathrm{NaF}$ and stored at room temperature increased its lactate to $0.068 \mathrm{mmol} / 1$ in the first 15 minutes after sampling. Following 14 days of storage at $4{ }^{\circ} \mathrm{C}$, there was a minimal increase of $0.026 \mathrm{mmol} / \mathrm{l}$ in the centrifuged samples. Their data indicated that the increase of lactate was due to continued lactate production by the blood cells in the first 15 minutes after blood collection.

In our tests, however, this effect is much less pronounced in diluted, not centrifuged, blood stored at room temperature. After a steep initial increase the curve for this series (fig. 6) levels off and shows no further marked lactate production during the next 90 minutes. The increase up to the plateau is, on the average, $30 \%$ above the initial value in the concentration range $0.6-2.0 \mathrm{mmol} / 1$. The stabilizing effect of the $\mathrm{NaF}$ is visible in phase 2 of the curve but it does not prevent the fast initial increase. The utilization of $\mathrm{NaF}$ alone as a stabilizing agent is not sufficient in this particular situation.

Lactate concentration does not change if heparinized whole blood is diluted immediately after sampling with $0.1 \mathrm{~mol} / \mathrm{l}$ phosphate buffer $\mathrm{pH}=7.3+2 \mathrm{~g} / 1 \mathrm{NaF}$ at a ratio of $1: 5$ (or 1:10) and the diluted blood is immediately placed in an ice bath. There were no deviations from the initial value in all 7 samples treated in this manner over the entire observation time of 2 hours.
This interval should be sufficient for the daily routine application where it is not always possible to determine lactate immediately after sample collection.

The following practical possibilities exist for the optimum determination of lactate:

1. Heparinized whole blood should be diluted with buffer immediately after sampling arld the lactate determined with the Lactate Analyzer without delay ( $<3$ minutes).

2. If it is not possible to determine the lactate immediately after sampling, one can either:

a) extend the time between blood withdrawal and measurement to at least 90 minutes by placing immediately the heparinized sample in an ice bath. In this manner no significant changes will be observed.

b) Dilute the sample with the appropriate buffer and place it also immediately in an ice bath. No change in lactate concentration will be observed at least for the next 120 minutes.

With the exception of unusually high levels of uric acid, none of the reducing substances found in blood interfere with the enzyme reaction used. Even the uric acid effect is minimal at commonly encountered uric acid levels. The drugṣ tested did not cause an effect. Drugs which potentiate or inhibit enzyme acitivity are a potential source of erroneous results. However, none has been found by us among drugs commonly used in situations where lactate determinations would be of clinical interest. Drug therapy might also affect the usable lifetime of the sensor without affecting the lactate results. This would be particularly true of drugs containing heavy metals such as mercury.

The Lactate Analyzer permits lactate determinations within 2-3 minutes of the time when blood is drawn. This is a decisive advantage for critically ill patients. The luxury of a rapid result is not possible with the spectrophotometric method since the classical method requires $1 \frac{1}{2}$ to 2 hours. However, certain automatic discrete sample analyzers now becoming available in large clinical laboratories require about the same amount of time per analysis as does this single purpose analyzer. A large discrete sample analyzer would not be as satisfactory as the lactate analyzer since it could not be placed in the patient area, thus producing a time delay between sampling and analysis which could cause an increase in lactate level.

\section{Acknowledgements}

We are thankful to Miss Schnepf and to Miss Hofer of the Department Internäl Medicine IV (Director: Prof. Dr. M. Eggstein) who performed the spectrophotometric assays of lactate. 


\section{References}

1. Peretz, D. I., Scott, H. M., Duff, J., Dossetor, J. B., MacLcan, L. D. \& McGregor, M. (1965), Ann. N. Y. Acad. Sci. 119, $1133-1141$

2. Weil, M. H. \& Afifi, A. A. (1970), Circulation 41, 9891001 .

3. Danicl, S. S. \& James, L. S. (1965), Ann. N. Y. Acad. Sci. $119,11.42-1152$.

4. Williams, D. L., Doig, A. R. \& Korosi, A. (1970), Anal. Chem. 42, 118-121.

5. Racinc, Ph. \& Mindt, W. (1971) in Biological Aspects of Electrochemistry, Experientia Suppl. Bd. 18, S. 525-534, Birkhäuser Verlag, Bascl.

6. Racinc, Ph., Mindt, W. \& Schläpfer, P. (1973), Proceedings on Electrochemical Bioscience and Bioengineering. Electrochemical Society Meeting, Chicago, May 1973.

7. Racine, Ph., Mindt, W., Rossel, C. \& Schläpfer, P. (1973, Procecdings of the 10th Int. Conference on Medical and Biological Engincering August 1973, Dresden, GDR.
8. Racine, Ph., Engelhard, R., Higelin, J. C. \& Mindt, W. (1975), Medical Instrumentation 9, 11-14.

9. Dikstein, S. (1959), Biochem. Biophys. Acta 36, 317-401.

10. Armstrong, I. McD. (1965), Ann. N. Y. Acad. Sci. 119, 817-885.

11. Westgard, J. O., Lahmeyer, B. L. \& Birnbaum, M. L. (1972), Clin. Chem. 18, 1334-1338.

12. Hohorst, H. J. (1957), Biochem. Z. 328, 509.

13. Linden, U.: Bestimmung von Lactat, Pyruvat und Acetat im Blut. Untersuchungen über Empfindlichkeit und Zuverlässigkeit des enzymatischen Nachweises. Dissertation, Tübingen (1966).
Dr. med. H.-O. Klenk
Med. Univ.-Klinik
Abtcilung Innere Medizin III
D-74 Tübingen
Otfried-Müllcr-Straße
Germany-W. 
